\title{
KEBUTUHAN MENCARI VARIASI MEMODERASI PENGARUH KEPUASAN PELANGGAN SMARTPHONE SAMSUNG TERHADAP NIAT BERPINDAH MEREK DI DENPASAR
}

\author{
Rizki Rachmad Dwinanto ${ }^{1}$ \\ I Gst. A. Kt. Gd. Suasana² \\ ${ }^{1,2}$ Fakultas Ekonomi dan Bisnis Universitas Udayana (Unud), Bali, Indonesia \\ e-mail: rizkirachmaddwinanto@gmail.com
}

\begin{abstract}
ABSTRAK
Pengguna smartphone kian berkembang pesat. Di Indonesia smartphone Samsung sudah sangat dikenal masyarakat. Penelitian ini bertujuan menjelasksan pengaruh kepuasan pelanggan terhadap niat berpindah merek, serta peran kebutuhan mencari variasi memoderasi pengaruh kepuasan pelanggan terhadap niat berpindah merek pada pengguna produk smartphone merek Samsung di Kota Denpasar. Penelitian ini menggunakan teknik pengumpulan sampel non probability sampling dengan metode purposive sampling, dengan menggunakan 140 responden yang merupakan pengguna produk smartphone merek Samsung, dan dilakukan di Kota Denpasar. Penelitian ini menggunakan teknik analisis data berupa Moderated Regression Analysis. Berdasarkan analisis yang dilakukan, diperoleh kepuasan pelanggan berpengaruh negatif signifikan terhadap niat berpindah merek, serta kebutuhan mencari variasi mampu memperlemah pengaruh kepuasan pelanggan terhadap niat berpindah merek. Implikasi penelitian ini secara teoritis sebagai tambahan refrensi penelitian selanjutnya yang berkaitan dengan niat berpindah merek. Disisi lain implikasi praktis penelitian ini sebagai tambahan informasi bagi perusahaan Samsung agar selalu berinovasi sesuai dengan kebutuhan variasi dari konsumen.
\end{abstract}

Kata kunci: kepuasaan pelanggan, kebutuhan mencari variasi, niat berpindah merek.

\begin{abstract}
Smartphone users now growing rapidly. In Indonesia, the Samsung's smartphone is well known to the public. This study aims to explain the effect of customer satisfaction on brand shifting intentions, as well as the role of variation-seeking needs to moderate the effect of customer satisfaction on the intention of switching brands on users of Samsung brand smartphone products in Denpasar City. This study uses data analysis techniques such as Moderated Regression Analysis. Based on the analysis, customer satisfaction has significant negative effect on brand switching intentions, and the need to find variation is able to weaken the influence of customer satisfaction on brand switching intention. The implications of this research are theoretically in addition to the subsequent refrentions pertaining to brandswitching intentions. On the other hand practical implications of this research as additional information for Samsung company to always innovate in accordance with the needs of variations from consumers.
\end{abstract}

Keywords: customer satisfaction, needs for variation, brand switching intention. 
Rizki Rachmad Dwinanto, Peran Kebutuhan Mencari Variasi...

\section{PENDAHULUAN}

Smartphone dan sosial media dapat meghubungkan dua atau lebih penggunanya, serta dapat memperoleh informasi lebih cepat dan lebih mudah dari biasanya (Goleman, 2011). Pengguna smartphone saat ini kian berkembang pesat. Hal tersebut dapat dilihat bahwa pengguna smartphone di Indonesia pada tahun 2015 mencapai 52,2 juta orang, pada tahun 2016 mencapai 69,4 juta orang, dan pada tahun 2017 mencapai 86,6 juta orang (id.techinasia.com).

Pengguna smartphone di Indonesia sangat beragam, mulai dari anak-anak, remaja hingga orang dewasa, serta tidak ada batasan gender dan pekerjaan, karena memang smartphone bisa membantu aktivitas dan keseharian penggunanya, mulai dari hiburan perorangan sampai kepada hal yang menyangkut kepentingan bersama, seperti bisnis, rapat kerja dan sebagainya. Smartphone merek Samsung sudah tidak asing lagi bagi masyarakat di Indonesia. Samsung Group berdiri pada 1 Maret 1938 di Daegu, Korea Selatan, dimana smartphone Samsung merupakan anak perusahaan Samsung Electronics Co, Ltd. Data dari IDC Quaterly Mobile Phone Tracker yang dikutip dari tekno.kompas.com, Samsung masih mengkokohkan posisinya di peringkat pertama pangsa pasar smartphone di Indonesia.

Berikut 5 besar peringkat smartphone di Indonesia pada kuartal III tahun 2017, disajikan pada Tabel 1 . 
Tabel 1.

Pangsa Pasar Smartphone di Indonesia Kuartal III Tahun 2017

\begin{tabular}{ccc}
\hline No. & Merek & Pangsa Pasar (\%) \\
\hline 1. & Samsung & 30,0 \\
2. & Oppo & 25,5 \\
3. & Advan & 8,3 \\
4. & Vivo & 7,5 \\
5. & Xiaomi & 6,2 \\
6. & Lainnya & 22,5 \\
\hline \multicolumn{2}{l}{}
\end{tabular}

Tabel 1 menunjukan Samsung kokoh pada peringkat pertama pangsa pasar di Indonesia, dengan pangsa pasar sebesar 30,0 persen. Dibawah merek Samsung ada tiga produsen smartphone asal China yaitu Oppo dengan pangsa pasar 25,5 persen, Vivo 7,5 persen, dan Xiaomi 6,2 persen. Advan satu-satunya merek lokal yang berada pada peringkat 5 besar dengan pangsa pasar 8,3 persen, sedangkan 22,5 persen merupakan gabungan merek smartphone lainnya seperti Apple, Asus, Lenovo, Smartfren. Pesatnya perkembangan smartphone saat ini, dan juga diiringi oleh semakin variatifnya permintaan konsumen akan fitur smartphone, membuat para produsen menciptakan inovasi akan produk-produknya, guna memenuhi kebutuhan konsumen yang turut berkembang tersebut. Namun karena banyaknya inovasi tersebut, membuat calon konsumen merasa bingung untuk melakukan keputusan pembeliannya

Fenomena yang terjadi sekarang pada sebagian besar masyarakat adalah smartphone tidak hanya berperan sebagai pemenuh kebutuhan akan teknologi dan informasi saja, melainkan sebagai gaya hidup, dan dukungan status sosial masyarakat. Hal tersebut ditunjukan ketika seseorang memiliki smartphone yang sudah memenuhi kebutuhannya dan tidak jarang ingin mengganti smartphone-nya dengan yang terbaru, atau memiliki dua smartphone dengan merek yang berbeda, sehingga membuat konsumen kurang setia pada merek smartphone yang digunakan 
Rizki Rachmad Dwinanto, Peran Kebutuhan Mencari Variasi...

pada saat itu. Perusahaan harus melakukan berbagai macam strategi pemasaran guna memperoleh dan mempertahankan pasar mereka, salah satunya adalah dengan cara diferensiasi. Diferensiasi selama ini diwujudkan dalam bentuk harga dan inovasi produk. Jika perusahaan tidak segera melakukan strategi pemasaran yang cocok berdasarkan kondisi pasar yang ada, maka pangsa pasar perusahaan tersebut harus siap diambil oleh pesaing. Hal tersebut didukung oleh hasil pra survei yang sudah dilakukan berupa wawancara tidak terstruktur pada 10 orang pengguna smartphone yang berdomisili di Denpasar. Hasilnya menunjukan bahwa delapan orang diantaranya merasa ingin melakukan pergantian smartphone, dan lima orang diantaranya merasa ingin melakukan pergantian merek.

Menurut Rizan dkk. (2012) loyalitas pelanggan menunjukan kesetiaan pelanggan atau konsumen pada objek tertentu, seperti merek, produk, jasa, atau toko. Djan dan Ruvendi (2006) menyatakan bahwa brand switching adalah berpindahnya kesetiaan konsumen baik pribadi maupun kelompok dari satu merek sebuah produk tertentu ke merek produk lainnya. Peralihan merek adalah proses di mana pelanggan beralih dari penggunaan satu produk ke produk lain, namun dalam kategori yang sama (Kumar dan Chaarlas, 2011). Perpindahan merek banyak terjadi pada pelanggan yang mengalami ketidakpuasan, karena pelanggan yang tidak puas akan mencari informasi pilihan produk lain dan mungkin akan berhenti membeli produk atau mempengaruhi orang lain untuk tidak membeli (Kotler \& Keller, 2008:177-193).

Perilaku berpindah (switching behaviour) dapat dinyatakan sebagai proses yang setia pada satu layanan dan akhirnya beralih ke layanan lain, karena 
ketidakpuasan atau masalah lain. Perpindahan merek dapat dipengaruhi oleh ketidakpuasan pelanggan terhadap suatu merek atau produk. Hoyer dan Ridgway (1984) dalam Setiyaningrum (2007) menyatakan bahwa ketidakpuasan pelanggan terhadap merek produk yang digunakan sebelumnya merupakan faktor yang menyebabkan terjadinya perpindahan merek. Jika konsumen setia kepada merek tertentu, jika merek tidak memenuhi kebutuhannya, konsumen akan beralih ke merek pesaing.

Uturestantix et al. (2012) menyatakan bahwa ketidakpuasan pelanggan berpengaruh positif terhadap keputusan perpindahan merek pada mahasiswa yang menggunakan GSM sebagai kartu prabayar. Hal tersebut didukung oleh Suharseno dkk. (2013) bahwa ketidakpuasan pelanggan berpengaruh positif dan signifikan terhadap keputusan konsumen perpindahan merek produk ponsel pada pengguna handphone di Kabupaten Rembang. Hal ini memiliki pengertian yang serupa bahwa kepuasan pelanggan berpengaruh negatif signifikan terhadap niat berpindah merek. Pelanggan yang puas dan cenderung loyal terhadap suatu merek mempunyai kecenderungan lebih rendah untuk berpindah (Wijayanti, 2008). Kepuasan pelanggan sangat erat hubungannya dengan loyalitas merek atau lawan dari niat berpindah merek, akan tetapi pelanggan yang puas akan suatu produk atau jasa tertentu, belum tentu loyal terhadap merek tersebut. Hal ini disebabkan oleh tingkat kebutuhan mencari variasi dari masing-masing individu. Menurut Peter dan Olson (2003 : 183) kebutuhan mencari variasi (variety seeking) adalah sebuah komitmen kognitif untuk membeli merek yang berbeda karena berbagai alasan yang berbeda, keinginan baru atau timbulnya rasa bosan pada sesuatu yang telah lama dikonsumsi. 
Rizki Rachmad Dwinanto, Peran Kebutuhan Mencari Variasi...

Berdasarkan latar belakang yang sudah diuraikan serta masih minimnya penelitian yang berhubungan dengan variabel diatas, maka diperlukan suatu penelitian lebih lanjut yang berhubungan dengan variabel-variabel tersebut. Penelitian ini diharapkan dapat menjawab hipotesis serta dapat dirasakan manfaatnya bagi pihak-pihak yang membutuhkan.

Tujuan yang hendak dicapai dalam penelitian ini berdasarkan latar belakang yang telah dijabarkan adalah untuk menjelaskan pengaruh kepuasan pelanggan terhadap niat berpindah merek smartphone Samsung di Kota Denpasar. Serta untuk menjelaskan peran kebutuhan mencari variasi dalam memoderasi pengaruh kepuasan pelanggan terhadap niat berpindah merek smartphone Samsung di Kota Denpasar. Penelitian ini diharapkan dapat menambah pengetahuan, wawasan serta informasi. Selain itu penelitian ini juga diharapkan dapat dijadikan sebagai referensi untuk penelitian selanjutnya yang bertujuan untuk mengembangkan ilmu pengetahuan terutama mengenai pengaruh kepuasan pelanggan terhadap perpindahan merek dengan kebutuhan mencari variasi sebagai variabel moderasi. Penelitian ini juga diharapkan dapat menjadi pedoman bagi konsumen dalam menentukan keputusan pembelian di masa yang akan datang yang berkaitan dengan pengaruh kepuasan pelanggan terhadap perpindahan merek dengan kebutuhan mencari variasi sebagai variabel moderasi.

Brand switching adalah saat dimana seorang konsumen atau sekelompok konsumen berpindah kesetiaan dari satu merek sebuah produk tertentu ke merek produk lainnya (Djan dan Ruvendi, 2006). Produsen yang tidak mampu memenuhi kebutuhan dan keinginan konsumen akan berdampak pada menurunnya tingkat 
loyalitas konsumen yang menyebabkan adanya perilaku perpindahan merek yang dilakukan konsumen. (Arianto, 2013).

Afzal et al. (2013) menyatakan bahwa perpindahan merek adalah proses dimana konsumen beralih dari penggunanaan satu produk ke peroduk lainnya dari kategori yang sama. Kanwal dan Lodhi (2015) mengatakan perpindahan merek mengacu pada keadaan yang situasional seperti yang dilakukan konsumen untuk berpindah dari satu merek ke merek lain. Menurut Kwifi dan Mc Naughton (2013)

perilaku brand switching sangat penting bagi persaingan antar produsen, dimana cara satu-satunya bagi produsen untuk memperluas pangsa pasar adalah dengan menganjurkan pengguna atau konsumen untuk beralih dari pesaing. Menurut Acharya dan Gupta (2014) tiga fokus utama dalam melihat faktor yang mempengaruhi perpindahan merek adalah konteks situasional, bauran pemasaran, serta tipe dari konsumen tersebut.

Konsumen melakukan brand switching tentu karena adanya pertimbangan yang telah dilewati. Chatrin dan Karlina (2007), munculnya perilaku brand switching dipengaruhi oleh banyak faktor. Faktor-faktor tersebut antara lain :

\section{1) Price}

Penetapan harga merupakan suatu alasan yang menyebabkan konsumen pindah ke merek yang lain, yang terdiri dari harga perbandingan, biaya, pembebanan, denda dan kesepakatan harga promosi.

\section{2) Sales Promotion}

Sales promotion adalah suatu cara untuk mempengaruhi konsumen agar langsung membeli barang dengan merek tertentu, sehingga dengan adanya 
Rizki Rachmad Dwinanto, Peran Kebutuhan Mencari Variasi...

sales promotion yang baik akan mempengaruhi konsumen dalam berpindah merek.

3) Munculnya Produk-Produk Baru

Munculnya pesaing-pesaing baru memang menjadi salah satu penyebab terjadinya brand switching.

4) Kualitas

Perilaku brand switching juga dipengaruhi oleh persepsi kualitas konsumen. Kualitas yang lebih baik dapat mempengaruhi konsumen untuk melakukan brand switching dari suatu produk yang satu ke produk yang lain.

Dharmmesta dan Shellyana (2002), serta Wibowo dkk. (2014) menyatakan bahwa perpindahan merek dapat diukur melalui indikator-indikator sebagai berikut:

1) Ketidakpuasan pasca konsumsi

2) Keinginan untuk mempercepat penghentian suatu barang atau jasa

3) Ketidakbersediaan menggunakan merek ulang.

Setiap pelanggan melakukan pembelian mempunyai harapan tertentu terhadap produk yang ia gunakan dan kepuasan merupakan hasil yang diharapkan. Kepuasan pelanggan adalah konsep kunci dibidang pemasaran dan manajemen, terutama di industri jasa (Heung and Gu, 2012). Kepuasan digunakan sebagai penilaian evaluasi dari suatu kesempatan pembelian yang spesifik (Ekinci et al., 2008). Kepuasan pelanggan merupakan hal yang krusial dalam menentukan suksesnya suatu bisnis (Anita dan Gede, 2015). Menurut Kotler dan Keller (2009 : 170) ketidakpuasan adalah suatu keadaan dimana pengharapan pelanggan tidak sama atau lebih tinggi dari pada kinerja yang diterimanya dari pemasar. Rosi dkk. 
(2012) menyatakan bahwa ketidakpuasan pelanggan berpengaruh secara positif dan signifikan terhadap perpindahan merek pada mantan pengguna kartu prabayar IM3 di lingkungan mahasiswa Universitas Diponegoro. Begitu juga dengan Uturestantix et al. (2012) juga menyatakan bahwa ketidakpuasan pelanggan berpengaruh secara positif terhadap perpindahan merek pada pasar telepon genggam di Asia Tenggara. Hal yang serupa dikemukakan oleh Suharseno dkk. (2013) bahwa ketidakpuasan pelanggan berpengaruh positif dan signifikan terhadap perpindahan merek produk ponsel. Berdasarkan teori yang telah dijelaskan dan hasil penelitian yang telah dilakukan sebelumnya, maka dalam penelitian ini diusulkan hipotesis sebagai berikut:

$\mathrm{H}_{1}$ : Kepuasan pelanggan berpengaruh negatif dan signifikan terhadap niat berpindah merek

Peter dan Olson (2003 : 183) menyatakan bahwa kebutuhan mencari variasi (variety seeking) adalah sebuah komitmen kognitif untuk membeli merek yang berbeda karena berbagai alasan yang berbeda, keinginan baru atau timbulnya rasa bosan pada sesuatu yang telah lama dikonsumsi. Ketika pelanggan merasa bosan atau merasa tidak puas dengan sebuah produk yang mereka gunakan sekarang, pada kasus ini adalah produk smartphone, mereka kemudian akan mencoba mencari variasi produk lainnya (Sulistyaningrum, 2012). Konsumen yang mempunyai keterlibatan emosional yang rendah terhadap suatu merek akan mudah berpindah pada merek pesaing (Arianto, 2013). Konsumen yang dihadapkan dengan berbagai variasi produk dengan berbagai jenis merek yang ditawarkan dapat mempengaruhi konsumen untuk mencoba-coba berbagai macam produk dan merek sehingga konsumen tidak akan sepenuhnya setia pada satu merek saja (Andriani dan 
Rizki Rachmad Dwinanto, Peran Kebutuhan Mencari Variasi...

Untarini, 2015). Berdasarkan penelitian sebelumnya yang dilakukan oleh Wibowo dkk. (2014) dan Arianto (2013) kebutuhan mencari variasi dapat diukur berdasarkan indikator-indikator berikut :

1) Kebutuhan akan variasi.

2) Adanya merek pilihan.

3) Perbedaan yang dirasakan antar merek.

Hasil penelitian sebelumnya yang dilakukan oleh Suharseno dkk. (2013) menyatakan bahwa ketidakpuasan konsumen lebih berpengaruh pada perpindahan merek ketika dimoderasi oleh kebutuhan mencari variasi pada produk smartphone. Namun Indarwati dan Untarini (2017) menyatakan bahwa kebutuhan mencari variasi tidak dapat memoderasi ketidakpuasan konsumen pada pengguna smartphone di Surabaya. Hal yang sama juga di kemukakan oleh Andriarso (2013) bahwa kebutuhan mencari variasi tidak mampu memoderasi ketidakpuasan konsumen terhadap keputusan perpindahan merek. Berdasarkan teori yang telah dijelaskan dan hasil penelitian yang telah dilakukan sebelumnya, maka dalam penelitian ini diusulkan hipotesis sebagai berikut:

$\mathrm{H}_{2}$ : Kebutuhan mencari variasi mampu memperlemah pengaruh kepuasan pelanggan terhadap niat berpindah merek

\section{METODE PENELITIAN}

Pendekatan yang digunakan dalam penelitian ini adalah pendekatan kuantitatif sedangkan metode penelitian yang digunakan adalah asosiatif. Penelitian ini dilakukan di Kota Denpasar. Pemilihan Kota Denpasar sebagai wilayah penelitian ini dikarenakan Kota Denpasar adalah ibu kota provinsi Bali dengan 
jumlah penduduk mencapai 636.599 jiwa dimana 462.860 jiwa adalah di rentang umur produktif 15 - 49 tahun (bps.denpasarkota.go.id).

Obyek dari penelitian ini adalah perilaku konsumen pengguna smartphone merek Samsung di Kota Denpasar mengenai keinginan berpindah merek yang dipengaruhi oleh variabel kepuasan pelanggan dengan kebutuhan mencari variasi sebagai variabel moderasi. Penelitian ini menggunakan 3 variabel yang terdiri dari 1 variabel terikat dan 2 variabel bebas. Variabel yang digunakan adalah niat berpindah merek (Y). Variabel bebas yang digunakan adalah kepuasan pelanggan $\left(\mathrm{X}_{1}\right)$, dan kebutuhan mencari variasi $\left(\mathrm{X}_{2}\right)$.

Setiap pelanggan melakukan pembelian mempunyai harapan tertentu terhadap produk yang ia gunakan dan kepuasan merupakan hasil yang diharapkan. Kepuasan atau ketidakpuasan pelanggan bergantung pada anggapan kinerja produk dalam menyerahkan nilai relatif terhadap harapan pembeli. Bila kinerja atau prestasi sesuai bahkan melebihi harapan, pembeli merasa puas. Menurut Pohan (2007:144) indikator pengukuran kepuasan pelanggan adalah sebagai berikut:

1) Kepuasan terhadap performa.

Pelanggan merasa puas atau senang terhadap performa smartphone merek Samsung dengan menggunakan indikator sebagai berikut :

a. Kepuasan Kinerja Prosesor

Smartphone Samsung memiliki kinerja prosesor yang baik $\left(\mathrm{X}_{1.1 .1}\right)$

b. Kepuasan Kapasitas RAM

Smartphone Samsung memiliki kapasitas RAM yang besar $\left(\mathrm{X}_{1.1 .2}\right)$

c. Kepuasan Kapasitas Memori 
Rizki Rachmad Dwinanto, Peran Kebutuhan Mencari Variasi...

Smartphone Samsung memiliki kapasitas memori yang besar $\left(\mathrm{X}_{1.1 .3}\right)$

2) Kepuasan terhadap fitur.

Pelanggan merasa puas atau senang terhadap keunggulan fitur smartphone merek Samsung dengan indikator sebagai berikut :

a. Kepuasan Kinerja Kamera

Smartphone Samsung memiliki kinerja kamera yang baik $\left(\mathrm{X}_{1.2 .1}\right)$

b. Kepuasan Kinerja Jaringan Internet

Smartphone Samsung memiliki kinerja jaringan internet yang cepat $\left(\mathrm{X}_{1.2 .2}\right)$

c. Kepuasan Kinerja Keamanan

Smartphone Samsung memiliki kinerja keamanan yang baik $\left(\mathrm{X}_{1.2 .3}\right)$

3) Keunggulan produk

Smartphone Samsung menawarkan fitur yang tidak ada pada smartphone merek lain $\left(\mathrm{X}_{1.3}\right)$

4) Terpenuhinya harapan.

Smartphone Samsung memberikan kinerja yang sesuai dengan harapan pelanggan $\left(\mathrm{X}_{1.4}\right)$

Kebutuhan mencari variasi (variety seeking) adalah sebuah komitmen kognitif untuk membeli merek yang berbeda karena berbagai alasan yang berbeda, keinginan baru atau timbulnya rasa bosan pada smartphoneyang digunakan sekarang. Wibowo dkk. (2014) dan Arianto (2013) kebutuhan mencari variasi dapat diukur berdasarkan indikator-indikator berikut :

1) Kebutuhan akan variasi 
Keinginan menggunakan smartphone merek lain ketika sedang menggunakan smartphone Samsung $\left(\mathrm{X}_{2.1}\right)$

2) Adanya merek pilihan.

Pelanggan merasa tidak hanya menyukai smartphone merek Samsung saja $\left(\mathrm{X}_{2.2}\right)$

3) Perbedaan yang dirasakan antar merek

Pelanggan menyadari adanya aspek lain yang ditawarkan diluar produk smartphone merek Samsung $\left(\mathrm{X}_{2.3}\right)$

Perpindahan merek adalah saat dimana seorang konsumen atau sekelompok konsumen berpindah kesetiaan dari satu merek sebuah produk smartphone tertentu ke merek produk smartphone lainnya. Dharmmesta dan Shellyana (2002), serta Wibowo dkk. (2014) menyatakan bahwa perpindahan merek dapat diukur melalui indikator-indikator sebagai berikut:

1) Ketidakpuasan pasca konsumsi

Pelanggan merasa tidak puas atau tidak sesuai harapan setelah melakukan pembelian smartphone merek Samsung $\left(\mathrm{Y}_{1.1}\right)$

2) Mempercepat penghentian penggunaan

Keinginan untuk mempercepat penghentian suatu barang atau jasa adalah rasa dimana konsumen memiliki ketertarikan terhadap produk smartphone sejenis pada merek lain $\left(\mathrm{Y}_{1.2}\right)$

3) Ketidakbersediaan menggunakan merek ulang Pelanggan merasa tidak suka terhadap merek smartphone yang digunakan saat ini dan tidak berencana menggunakannya lagi $\left(\mathrm{Y}_{1.3}\right)$ 
Rizki Rachmad Dwinanto, Peran Kebutuhan Mencari Variasi...

Berdasarkan jenisnya, data yang digunakan dalam penelitian ini adalah data kualitatif dan data kuantitatif. Data kualitatif dinyatakan dalam bentuk kata serta kalimat seperti gambaran umum mengenai produk smartphone yang digunakan saat ini dan pendapat dari responden terhadap pernyataan yang diajukan dalam kuesioner. Data kuantitatif dinyatakan dalam bentuk angka atau data yang dapat dihitung seperti skor tanggapan terhadap kuesioner yang diberikan pada pengguna smartphone di Kota Denpasar. Sumber data yang digunakan dalam penelitian ini adalah data primer diperoleh langsung dari sumbernya dengan cara pengumpulan data menggunakan kuesioner. Data sekunder dalam penelitian ini bersumber dari studi pustaka melalui berbagai jurnal, penelitian skripsi, maupun artikel yang diambil dari internet misalnya id.techinasia.com untuk mendapatkan data yang berhubungan dengan variabel yang dibutuhkan dalam penelitian ini.

Populasi dalam penelitian ini adalah seluruh pengguna smartphone merek Samsung di Kota Denpasar. Dalam penelitian ini digunakan 14 indikator sehingga minimal banyaknya responden yang menjadi anggota sampel adalah 70 responden, sedangkan maksimal responden yang menjadi anggota sampel adalah 140 responden. Jumlah responden yang diambil adalah sebanyak 100 responden.

Dalam penelitian ini digunakan teknik pengumpulan sampel non probability sampling dengan metode purposive sampling yaitu teknik penentuan sampel dengan pertimbangan tertentu. Metode pengumpulan data dalam penelitian ini adalah metode survei dengan teknik wawancara menggunakan kuesioner. Teknik analisis data yang digunakan dalam penelitian ini adalah regresi linier berganda dan moderated regression analysis. 


\section{PEMBAHASAN}

Menurut Sugiyono (2014:147) instrumen yang valid berarti alat ukur yang digunakan dengan mendapatkan data (mengukur) itu valid. Validitas dilakukan dengan menghitung korelasi antara skor faktor dengan skor total dan bila korelasi setiap faktor tersebut bernilai positif, maka instrumen penelitian tersebut dapat dikatakan valid. Hasil uji validitas dapat dilihat pada Tabel 2. berikut :

Tabel 2.

Hasil Uji Validitas

\begin{tabular}{|c|c|c|c|}
\hline Variabel & Instrumen & Koefisien Korelasi & Keterangan \\
\hline \multirow{8}{*}{$\begin{array}{c}\text { Kepuasan Pelanggan } \\
\text { (X1) }\end{array}$} & $\mathrm{X} 1.1$ & 0,725 & Valid \\
\hline & $\mathrm{X} 1.2$ & 0,638 & Valid \\
\hline & $\mathrm{X} 1.3$ & 0,623 & Valid \\
\hline & $\mathrm{X} 1.4$ & 0,562 & Valid \\
\hline & $\mathrm{X} 1.5$ & 0,614 & Valid \\
\hline & $\mathrm{X} 1.6$ & 0,486 & Valid \\
\hline & $\mathrm{X} 1.7$ & 0,506 & Valid \\
\hline & $\mathrm{X} 1.8$ & 0,736 & Valid \\
\hline \multirow{3}{*}{$\begin{array}{l}\text { Kebutuhan Mencari Variasi } \\
\text { (X2) }\end{array}$} & $\mathrm{X} 2.1$ & 0,663 & Valid \\
\hline & $\mathrm{X} 2.2$ & 0,742 & Valid \\
\hline & $\mathrm{X} 2.3$ & 0,717 & Valid \\
\hline \multirow{3}{*}{$\begin{array}{l}\text { Niat Berpindah Merek } \\
\text { (Y) }\end{array}$} & Y.1 & 0,814 & Valid \\
\hline & Y.2 & 0,867 & Valid \\
\hline & Y.3 & 0,707 & Valid \\
\hline
\end{tabular}

Sumber: Data diolah, 2018

Berdasarkan Tabel . menunjukkan bahwa seluruh indikator dalam variabel kepuasan pelanggan, kebutuhan mencari variasi, dan niat berpindah merek memiliki nilai koefisien korelasi yang lebih besar dari angka 0,30 sehingga seluruh indikator tersebut dikatakan telah memenuhi syarat validitas data.

Selanjutnya dilakukan uji reliabilitas. Kuesioner dapat dikatakan reliabel atau handal apabila jawaban atas pertanyaan yang diberikan adalah konsisten atau dengan kata lain instrumen tersebut stabil dari waktu ke waktu (Ghozali, 2013:47). 
Tabel 3.

Hasil Uji Reliabilitas

\begin{tabular}{lcc}
\hline \multicolumn{1}{c}{ Variabel } & Cronbadh'sAlpha & Keterangan \\
\hline Kepuasan Pelanggan & 0,755 & Reliabel \\
Kebutuhan Mencari Variasi & 0,712 & Reliabel \\
Niat Berpindah Merek & 0,710 & Reliabel
\end{tabular}

Sumber: Data diolah, 2018

Hasil uji reliabilitas instrumen pada penelitian ini disajikan pada Tabel 3 yang menunjukkan bahwa ketiga instrumen penelitian yaitu kepuasan pelanggan, kebutuhan mencari variasi, dan niat berpindah merek memiliki koefisien cronbach's alpha yang lebih besar dari angka 0,60 sehingga pernyataan pada kuesioner dapat dikatakan reliable.

Variabel kepuasan pelanggan merupakan variabel pertama yang dimasukkan dalam penelitian ini dan dijadikan sebagai variabel bebas atau eksogen yang diukur dengan menggunakan delapan pernyataan indikator. Secara rinci, penilaian responden dapat dilihat pada Tabel 4.

Berdasarkan Tabel 4, dapat diketahui bahwa secara keseluruhan rata-rata penilaian responden terhadap variabel kepuasan pelanggan adalah sebesar 4,05 dan masuk dalam kriteria baik. Hal ini berarti responden memiliki perhatian yang tinggi terhadap indikator kepuasan pelanggan yang diterapkan pada produk smartphone merek Samsung. 
Tabel 4.

Deskripsi Persepsi Responden terhadap Kepuasan Pelanggan

\begin{tabular}{|c|c|c|c|c|c|c|c|c|}
\hline \multirow[t]{2}{*}{ Indikator } & \multicolumn{5}{|c|}{ Skor Jawaban } & \multirow{2}{*}{$\begin{array}{l}\text { Jumlah } \\
\text { Skor }\end{array}$} & \multirow{2}{*}{$\begin{array}{l}\text { Rata- } \\
\text { Rata }\end{array}$} & \multirow{2}{*}{ Ket. } \\
\hline & 1 & 2 & 3 & 4 & 5 & & & \\
\hline $\begin{array}{l}\text { Smartphone Samsung memiliki } \\
\text { kinerja prosesor yang baik. }\left(\mathrm{X}_{1.1}\right)\end{array}$ & 0 & 0 & 18 & 74 & 48 & 590 & 4,21 & $\begin{array}{c}\text { Sangat } \\
\text { Baik }\end{array}$ \\
\hline $\begin{array}{l}\text { Smartphone Samsung memiliki } \\
\text { kapasitas RAM yang besar. }\left(\mathrm{X}_{1.2}\right)\end{array}$ & 0 & 3 & 23 & 90 & 24 & 555 & 3,96 & Baik \\
\hline $\begin{array}{l}\text { Smartphone Samsung memiliki } \\
\text { kapasitas memori yang besar. }\left(\mathrm{X}_{1.3}\right)\end{array}$ & 0 & 6 & 41 & 61 & 32 & 539 & 3,85 & Baik \\
\hline $\begin{array}{l}\text { Smartphone Samsung memiliki } \\
\text { kinerja kamera yang baik. }\left(\mathrm{X}_{1.4}\right)\end{array}$ & 0 & 0 & 8 & 72 & 60 & 612 & 4,37 & $\begin{array}{c}\text { Sangat } \\
\text { Baik }\end{array}$ \\
\hline $\begin{array}{l}\text { Smartphone Samsung memiliki } \\
\text { kinerja jaringan internet yang baik. } \\
\left(\mathrm{X}_{1.5}\right)\end{array}$ & 0 & 0 & 53 & 62 & 25 & 532 & 3,80 & Baik \\
\hline $\begin{array}{l}\text { Smartphone Samsung memiliki } \\
\text { kinerja keamanan yang baik. }\left(\mathrm{X}_{1.6}\right)\end{array}$ & 0 & 0 & 28 & 88 & 24 & 556 & 3,97 & Baik \\
\hline $\begin{array}{l}\text { Smartphone Samsung menawarkan } \\
\text { fitur yang tidak ada pada smartphone } \\
\text { merek lain. }\left(\mathrm{X}_{1.7}\right)\end{array}$ & 0 & 2 & 33 & 51 & 54 & 577 & 4,12 & Baik \\
\hline $\begin{array}{l}\text { Smartphone Samsung memberikan } \\
\text { kinerja yang sesuai dengan harapan } \\
\text { pelanggan. }\left(\mathrm{X}_{1.8}\right)\end{array}$ & 0 & 0 & 21 & 71 & 48 & 587 & 4,19 & Baik \\
\hline & & & & & & & 4,05 & Baik \\
\hline
\end{tabular}

Sumber: Data diolah, 2018

Berdasarkan hasil deskripsi penilaian responden terhadap variabel kepuasan pelanggan yang diukur dengan delapan indikator, menunjukkan nilai rata-rata tertinggi pada pernyataan "Smartphone Samsung memiliki kinerja kamera yang baik." dengan nilai rata-rata sebesar 4,37. Hal ini mengindikasikan bahwa secara keseluruhan kamera yang disematkan dalam smartphone Samsung memiliki kinerja yang sangat baik, sehingga menjadi nilai lebih bagi para pelanggan.

Variabel kebutuhan mencari variasi adalah variabel kedua yang dimasukkan dalam penelitian ini dan dijadikan sebagai vaiabel moderasi yang diukur dengan menggunakan tiga pernyataan indikator. Secara rinci, penilaian responden dapat dilihat pada Tabel 5 . 
Tabel 5.

Deskripsi Persepsi Responden terhadap Kebutuhan Mencari Variasi

\begin{tabular}{|c|c|c|c|c|c|c|c|c|}
\hline \multirow[t]{2}{*}{ Indikator } & \multicolumn{5}{|c|}{ Skor Jawaban } & \multirow{2}{*}{$\begin{array}{l}\text { Jumlah } \\
\text { Skor }\end{array}$} & \multirow{2}{*}{$\begin{array}{l}\text { Rata- } \\
\text { Rata }\end{array}$} & \multirow[b]{2}{*}{ Ket. } \\
\hline & 1 & 2 & 3 & 4 & 5 & & & \\
\hline $\begin{array}{l}\text { Keinginan menggunakan smartphone } \\
\text { merek lain ketika sedang } \\
\text { menggunakan smartphone Samsung. } \\
\left(\mathrm{X}_{2.1}\right)\end{array}$ & 0 & 4 & 60 & 69 & 7 & 499 & 3,56 & Baik \\
\hline $\begin{array}{l}\text { Saya menyukai smartphone merek } \\
\text { lain selain Samsung. }\left(\mathrm{X}_{2.2}\right)\end{array}$ & 0 & 4 & 48 & 78 & 10 & 514 & 3,67 & Baik \\
\hline $\begin{array}{l}\text { Saya menyadari produk smartphone } \\
\text { merek lain menawarkan fitur yang } \\
\text { lebih baik daripada merek Samsung. } \\
\left(\mathrm{X}_{2.3}\right)\end{array}$ & 2 & 7 & 76 & 48 & 7 & 471 & 3,36 & Cukup \\
\hline & $a-R$ & & & & & & 3,53 & Baik \\
\hline
\end{tabular}

Sumber: Data diolah, 2018

Data pada Tabel 5 menunjukkan bahwa secara keseluruhan rata-rata penilaian responden terhadap variabel kebutuhan mencari variasi adalah sebesar 3,53 dan masuk dalam kriteria baik. Hal ini mengindikasikan bahwa responden yang terlibat dalam penelitian ini memiliki rasa akan kebutuhan mencari variasi yang tinggi.

Berdasarkan hasil deskripsi penilaian responden terhadap variabel kebutuhan mencari variasi yang diukur dengan tiga indikator, menunjukkan nilai rata-rata tertinggi pada pernyataan "Saya menyukai smartphone merek lain selain Samsung" dengan nilai rata-rata sebesar 3,67. Hal ini mengindikasikan bahwa para pengguna smartphone mererk Samsung memiliki tingkat kebutuhan mencari variasi yang cukup tinggi, dikarenakan para responden menyukai smartphone merek lain selain Samsung.

Variabel niat berpindah merek adalah variabel ketiga dalam penelitian ini dan dijadikan sebagai variabel terikat atau endogen yang diukur dengan menggunakan tiga pernyataan indikator. Secara rinci, penilaian responden dapat dilihat pada Tabel 6. sebagai berikut : 
Tabel 6.

Deskripsi Persepsi Responden terhadap Niat Berpindah Merek

\begin{tabular}{|c|c|c|c|c|c|c|c|c|}
\hline \multirow[t]{2}{*}{ Indikator } & \multicolumn{5}{|c|}{ Skor Jawaban } & \multirow{2}{*}{$\begin{array}{c}\text { Jumlah } \\
\text { Skor }\end{array}$} & \multirow{2}{*}{$\begin{array}{l}\text { Rata- } \\
\text { Rata }\end{array}$} & \multirow{2}{*}{ Ket. } \\
\hline & 1 & 2 & 3 & 4 & 5 & & & \\
\hline $\begin{array}{l}\text { Perasaan tidak puas dengan } \\
\text { keputusan pembelian produk } \\
\left.\text { smartphone Samsung. ( } \mathrm{Y}_{1.1}\right)\end{array}$ & 39 & 70 & 29 & 2 & 0 & 274 & 1,95 & Buruk \\
\hline $\begin{array}{l}\text { Keinginan untuk segera beralih } \\
\text { menggunakan produk } \\
\text { smartphone merek lain }\end{array}$ & 48 & 64 & 23 & 3 & 2 & 267 & 1,90 & Buruk \\
\hline $\begin{array}{l}\text { Saya tidak bersedia } \\
\text { menggunakan merek smartphone } \\
\text { yang sama pada pembelian } \\
\text { berikutnya. }\left(\mathrm{Y}_{1.3}\right)\end{array}$ & 65 & 43 & 32 & 0 & 0 & 247 & 1,76 & $\begin{array}{l}\text { Sangat } \\
\text { Buruk }\end{array}$ \\
\hline & ata- & ata & & & & & 1,87 & Buruk \\
\hline
\end{tabular}

Sumber: Data diolah, 2017

Data pada Tabel 6 secara keseluruhan rata-rata penilaian responden terhadap variabel niat berpindah merek adalah sebesar 1,87 dan masuk dalam kriteria buruk. Hal ini mengindikasikan keinginan responden untuk berpindah merek smartphone ke merek selain Samsung masih kecil.

Berdasarkan hasil deskripsi penilaian responden terhadap variabel niat berpindah merek yang diukur dengan tiga indikator, menunjukkan nilai rata-rata tertinggi pada pernyataan "Perasaan tidak puas dengan keputusan pembelian produk smartphone Samsung" dengan nilai rata-rata sebesar 1,95. Hal ini mengindikasikan bahwa secara keseluruhan indikator perasaan puas atau tidak puas mempunyai peran tinggi dalam hal niat berpindah merek dari pengguna produk smartphone merek Samsung.

Selanjutnya dilakukan uji asumsi klasik ini untuk mendeteksi apakah model regresi disusun tidak terjadi bias. Hasil uji normalitas, Jika nilai Asymp. Sig. (2tailed) lebih besar taraf signifikansi yang ditetapkan yaitu 5 persen $(0,05)$. Dari uji ini diperoleh hasil sebesar 0,466 > 0,05 yang artinya data berdistribusi normal. 
Tabel 7.

Hasil Uji Normalitas

\begin{tabular}{lc}
\hline & Unstandardized Residual \\
\hline $\mathrm{N}$ & 140 \\
Kolmogrov-Smirnov-Z & 0,849 \\
Asymp.Sig.(2-tailed) & 0,466
\end{tabular}

Sumber: Data diolah, 2018

Untuk mengetahui keberadaan variabel - variabel yang saling berkorelasi kuat (multikolinearitas) pada model regresi dapat dilakukan dengan melihat nilai Variance Inflation Factor(VIF) dan nilai Tolerance dengan ketentuan VIF $<10$ dan Tolerance $>0.1$.

Tabel 8.

Hasil Uji Multikolinieritas

\begin{tabular}{|c|c|c|}
\hline \multirow[t]{2}{*}{ Model } & \multicolumn{2}{|c|}{ Colinearity Statistic } \\
\hline & Tolerance & VIF \\
\hline $\mathrm{X}_{1}$ & 0,791 & 1,264 \\
\hline $\mathrm{X}_{1} * \mathrm{X}_{2}$ & 0,791 & 1,264 \\
\hline
\end{tabular}

Sumber: Data diolah, 2018

Berdasarkan Tabel 8 Nilai VIF untuk setiap variabel bebas adalah lebih kecil dari 10 dengan Tolerance lebih besar dari 0.1 , hal ini berarti tidak terdapat multikolinearitas antar variabel dalam model regresi.

Guna melihat gejala heteroskedastisitas maka dilakukan Uji Glejser dengan meregresi nilai absolut terhadap variabel independen, dengan ketentuan jika nilai signifikan di atas 0,05 maka memiliki arti bahwa penelitian ini tidak terjadi heteroskedastisitas.

Tabel 9.

Hasil Uji Heteroskadstisitas

\begin{tabular}{|c|c|c|}
\hline Model & Sig. & Keterangan \\
\hline $\mathrm{X}_{1}$ & 0,093 & Lolos Uji \\
\hline $\mathrm{X}_{1} * \mathrm{X}_{2}$ & 0,063 & Lolos Uji \\
\hline
\end{tabular}

Sumber: Data diolah, 2018 
Tabel 9 Merupakan hasil tabel hasil uji Glejser, karena nilai signifikansi t setiap variabel lebih dari taraf nyata $\alpha=0.05$ maka tidak cukup bukti untuk menolak hipotesis nol yang berarti bawa tidak ada variabel bebas yang signifikan berpengaruh terhadap nilai mutlak dari sisaan (residuals), dengan demikian disimpulkan bahwa tidak terjadi heteroskedastisitas pada model regresi.

Penelitian ini menggunakan model Moderated Regression Analysis (MRA) dalam pengujian hipotesis. Rangkuman hasil pengolahan data tersebut dapat dilihat pada Tabel 10 sebagai berikut :

Tabel 10.

Rangkuman Hasil Moderated Regression Analysis (MRA)

\begin{tabular}{llrrrr}
\hline Variabel Terikat & Variabel Bebas & Koefisien Regresi & Std. Error & t-hitung & Signifikansi \\
\hline Y & konstanta & 13,232 & 1,366 & 9,687 & 0,000 \\
X1 & $-0,605$ & 0,045 & $-7,470$ & 0,000 \\
X1.X2 & $-0,432$ & 0,076 & $-2,781$ & 0,008 \\
\hline R-Square & 0,394 & & F-hitung & 27,902 \\
Adjusted R-Square & 0,383 & & Signikansi & 0,000 \\
\hline Sumber: Data diolah, 2018 & & &
\end{tabular}

Melalui data pada tabel 10 dapat diperoleh model persamaan regresi linear berganda sebagai berikut:

$$
\mathrm{Y}=13,232-0,605 \mathrm{X}_{1}-0,432 \mathrm{X}_{1} \mathrm{X}_{2}
$$

Nilai konstanta sebesar 13,232 memiliki arti apabila semua variabel independen konstan, maka niat berpindah merek pelanggan produk smartphone merek Samsung meningkat 13,232 persen. Nilai koefisien regresi kepuasan pelanggan (X1) sebesar -0,605 memiliki arti jika kepuasan pelanggan meningkat sebesar 1 persen, maka niat berpindah merek pelanggan produk smartphone merek Samsung akan menurun sebesar 0,605 persen. Nilai koefisien regresi interaksi 
Rizki Rachmad Dwinanto, Peran Kebutuhan Mencari Variasi...

kepuasan pelanggan (X1) dan kebutuhan mencari variasi (X2) sebesar -0,432 memiliki arti jika interaksi kepuasan pelanggan (X1) dan kebutuhan mencari variasi (X2) meningkat 1 satuan, maka niat berpindah merek pelanggan produk smartphone merek Samsung menurun sebesar 0,432 persen.

Adjusted $R^{2}=0,383$ yang artinya sebesar 38,3 persen variabel niat berpindah merek dipengaruhi oleh kepuasan pelanggan dan kebutuhan mencari variasi sebagai pemoderasi, sedangkan sisanya sebesar 61,7 persen dipengaruhi oleh faktor-faktor lain yang tidak dimasukkan ke dalam model penelitian.

Uji kelayakan model (Uji F) digunakan untuk mengetahui apakah model Moderated Regression Analysis (MRA) dalam penelitian ini layak digunakan. Pada Tabel 10 nilai signifikansi $\mathrm{F}$ adalah sebesar 0,000 yang lebih kecil dari $0,05(\mathrm{~F}<\alpha)$ yang berarti variabel bebas yaitu kepuasan pelanggan (X1) dan kebutuhan mencari variasi (X2) sebagai pemoderasi berpengaruh signifikan secara serempak atau bersama-sama terhadap variabel terikat yaitu niat bepindah merek (Y), sehingga penelitian ini dapat dikatakan memenuhi uji kelayakan model atau model penelitian dinyatakan layak digunakan sebagai model regresi.

Hasil pengujian menggunakan regresi moderasi menunjukkan bahwa koefisien regresi kepuasan pelanggan sebesar -0,605 dengan tingkat signifikansi 0,000 lebih kecil dari $\alpha(5 \%)$ yang sesuai dengan hipotesis yang diharapkan sehingga $\mathrm{H}_{1}$ diterima. Arah koefisien regresi kepuasan pelanggan yang negatif menunjukkan bahwa semakin tinggi kepuasan pelanggan maka akan menurunkan niat berpindah merek pada pengguna smartphone merek Samsung. Variabel kepuasan pelanggan memiliki nilai signifikansi lebih kecil dari 5 persen 
menunjukkan bahwa kepuasan pelanggan berpengaruh signifikan terhadap niat berpindah merek.

Penelitian ini mendukung penelitian terdahulu oleh Rosi dkk. (2012) yang menyatakan bahwa ketidakpuasan pelanggan berpengaruh secara positif dan signifikan terhadap perpindahan merek pada mantan pengguna kartu prabayar IM3 di lingkungan mahasiswa Universitas Diponegoro. Begitu juga dengan Uturestantix et al. (2012) juga menyatakan bahwa ketidakpuasan pelanggan berpengaruh secara positif terhadap perpindahan merek pada pasar telepon genggam di Asia Tenggara. Hal yang serupa dikemukakan oleh Suharseno dkk. (2013) bahwa ketidakpuasan pelanggan berpengaruh positif dan signifikan terhadap perpindahan merek produk ponsel.

Hasil pengujian dengan menggunakan regresi moderasi menunjukkan bahwa koefisien regresi variabel interaksi antara variabel kepuasan pelanggan dengan variabel kebutuhan mencari variasi menunjukkan nilai koefisien sebesar $-0,432$ dengan nilai signifikansi 0,008 lebih kecil dari $\alpha(5 \%)$ sehingga $\mathrm{H}_{2}$ diterima. Kebutuhan mencari variasi terbukti memperlemah hubungan kepuasan pelanggan terhadap niat berpindah merek karena nilai koefisien regresinya menjadi lebih besar dan tingkat signifikansinya terpenuhi. Ini berarti kebutuhan mencari variasi mampu memoderasi pengaruh kepuasan pelanggan terhadap niat berpindah merek pada pengguna produk smartphone merek Samsung.

Penelitian ini mendukung penelitian terdahulu oleh Suharseno dkk. (2013) menyatakan bahwa ketidakpuasan konsumen lebih berpengaruh pada perpindahan merek ketika dimoderasi oleh kebutuhan mencari variasi pada produk smartphone. 
Rizki Rachmad Dwinanto, Peran Kebutuhan Mencari Variasi...

Hal yang sama juga di kemukakan oleh Andriarso (2013) bahwa kebutuhan mencari variasi tidak mampu memoderasi ketidakpuasan konsumen terhadap keputusan perpindahan merek.

\section{SIMPULAN DAN SARAN}

Berdasarkan pengujian hipotesis yang telah dilakukan maka dapat disimpulkan beberapa hal sebagai berikut: 1) Variabel kepuasan pelanggan berpengaruh negatif dan signifikan terhadap niat berpindah merek pada pengguna produk smartphone merek Samsung. Hasil penelitian ini membuktikan bahwa semakin baik kepuasan pelanggan yang dirasakan oleh pengguna produk smartphone merek Samsung maka akan semakin rendah keinginan untuk berpindah merek. 2) Variabel kebutuhan mencari variasi mampu memperlemah pengaruh kepuasan pelanggan terhadap niat berpindah merek. Penelitian ini menunjukan bahwa semakin tinggi nilai kebutuhan mencari variasi dalam diri seseorang, maka akan membuat nilai kepuasan pelanggan terhadap niat berpindah merek semakin rendah. Hal ini membuktikan bahwa walaupun pelanggan puas terhadap suatu merek, belum tentu loyal terhadap merek tersebut, karena adanya faktor kebutuhan mencari variasi dari dalam diri seseorang.

Berdasarkan hasil dan pembahasan serta kesimpulan pada penelitian ini, adapun saran-saran yang dapat diberikan dalam penelitian ini, yaitu: 1) Perusahaan Samsung sebaiknya mampu mempertahankan kualitas produk yang diproduksi sehingga kepuasan pelanggannya tetap terjaga dan loyal terhadap merek Samsung. 2) Perusahaan Samsung juga tidak boleh lengah dalam hal menjaga pangsa pasar di Indonesia khususnya. Karena setiap pelanggan smartphone merek Samsung yang 
merasa puas, belum tentu loyal terhadap merek Samsung. Hal ini dikarenakan adanya faktor kebutuhan mencari variasi dalam diri seseorang, sehingga perusahaan Samsung harus tetap mengeluarkan variasi produknya demi memenuhi keinginan pelanggan. 3) Peneliti selanjutnya diharapkan mampu mengembangkan penelitian ini karena masih adanya keterbatasan penelitian yang telah disampaikan sebelumnya dan menambahkan faktor-faktor lain yang mampu memengaruhi hubungan antar variabel yang digunakan dalam penelitian ini.

\section{REFERENSI}

Acharya, Aditi., and Gupta, O.P. 2014. Influence of Peer Pressure on Brand Switching Among Indian College Students. International Journal of Current Research, 02, hal.5163-5171.

Afzal, Sarwat., Chandio, Aamir Khan., Shaikh, Sania., Bhand, Muskan., Ghumro.,Bais Ali., and Khuhro, Anum Kanwal. 2013. Factors Behind Brand Switching In Cellular Networks. International Journal of Asian Social Science, 3(2), hal.299-307.

Andriani, Rafita Eka dan Nindria Untarini. 2015. Pengaruh Ketidakpuasan Konsumen Dan Kebutuhan Mencari Variasi Terhadap Perpindahan Merek Mobile Broadband Smartfren. Jurnal Ilmu Manajemen, 1(1), hal.1-13

Andriarso, Nur Adicahya. 2013. Pengaruh Variety Seeking Sebagai Variabel Moderasi Terhadap Keputusan Perpindahan Merek. Fokus Manajerial, 12(1), hal.92-102

Anggraeni, Ratna Aristya Dewi dan I Gusti Agung Ketut Gede Suasana. 2014. Perilaku Beralih Konsumen Jasa Operator Axis di Kota Denpasar. E-Jurnal Manajemen Unud, 3(12), hal.3671-3694

Arianto, Anandhitya Bagus. 2013. Pengaruh Atribut Produk, Harga, Kebutuhan Mencari Variasi dan Ketidakpuasan Konsumen terhadap Keputusan Perpindahan Merek dari Samsung Galaxy Series di Kota Malang. Jurnal Aplikasi Manajemen, 11(2), hal.295-305

Chatrin dan Karlina, S. 2007. Analisa Faktor-Faktor Yang Mempengaruhi Konsumen Dalam Melakukan Brand Switching Terhadap Bread Boutiques Di Supermall Pakuwon Indah Surabaya. Jurnal Manajemen dan Kewiraushaan, 1(2), hal.01-17

Dharmmesta, B.S., dan Shellyana, J. 2002. Pengaruh Ketidakpuasan Konsumen, Karakteristik Produk, dan Kebutuhan Mencari Variasi Terhadap Keputusan 
Rizki Rachmad Dwinanto, Peran Kebutuhan Mencari Variasi...

Perpindahan Merek. Jurnal Ekonomi dan Bisnis Indonesia, 17(1), hal.91104.

Faustine, Megan. 2015. The Impact of Variety Seeking, Social Status, Quality and Advertisement Towards Brand Switching in Smartphone Product (A Case Study of BlackBerry User Thas Has Ever Changed Into Another Smartphone Product in Surabaya). iBuss Management, 3 (2), hal.142 - 153

Ghozali, Imam. 2013. Aplikasi Analisis Multivariate dengan Program SPSS. Edisi Keempat, Penerbit Universitas Diponogoro.

Heung, Vincent C.S. and $\mathrm{Gu}$ Tianming. 2012. Influence of Restaurant Atmospherics On Patron Satisfaction And Behavioral Intention. International Journal of Hospitality Management, 3(1), hal.1167-1177

Indarwati, Yuyun, dan Nindria Untarini. 2017. Pengaruh Ketidakpuasan Terhadap Keputusan Perpindahan Merek Dengan Kebutuhan Mencari Variasi Sebagai Variabel Moderasi. Jurnal Ilmu Manajemen, 5(1), hal.01-11

Kanwal, Ayesha., and Lodhi, Samreen. 2015. The International Journal of Business \& Management. The International Journal of Business \& Management, 3(11). Hal.49-56

Kotler, Philip, dan Keller, Kevin Lane, 2009, Manajemen Pemasaran. Jilid 1. Edisi 13. Jakarta: Penerbit Erlangga

Kotler, Philip, and Keller, Kevin Lane. 2008. Manajemen Pemasaran, Edisi 12,Jilid 1, Jakarta: Indeks.

Kotler, Philip, and Keller, Kevin Lane. 2009. Manajemen Pemasaran, Edisi 13,Jilid 1, Jakarta: Penerbit Erlangga.

Kraim, H. 2011. "The Influence Brand Loyalty on Cosmetics Buying Behavior of UAE Female Consumers. International Journal of Marketing Studies, 3(2), hal.123-133".

Kwifi, Sam O. Al-., and McNaughton, Rod B. 2013. The Influence of Product Features on Brand Switching: The Case of Magnetic Resonance Imaging Equipment. Journal of Business \& Industrial Marketing, hal.421-431.

Liana, Lie. 2009. Penggunaan MRA dengan SPSS untu Menguji Pengaruh Variabel Moderating terhadap Hubungan antara Variabel Independen dan Variabel Dependen. Jurnal Fakultas Ekonomi, 14(2), hal.90-97.

Marhaini, 2011. Analisis Perilaku Konsumen dalam Pembeliam Komputer Merek Acer (Studi Kasus: Mahasiswa Fakultas Ekonomi Universitas Sumatera Utara). Jurnal Manajemen Bisnis, 1(3). hal.89 - 96

Peter, J. Paul dan Jerry C. Olson. 2003. Perilaku Konsumen dan Strategi Pemasaran. 6 edition. Jakarta: Erlangga.

Pohan, Imbalo. 2007. Jaminan Mutu Layanan Kesehatan:Dasar-Dasar Pengertian dan Penerapan. Jakarta : Penerbit Buku Kedokteran EGC. 
Rosi, Janatien, Naili Farida, Agung Budiatmo. 2012. Pengaruh Ketidakpuasan dan Iklan Produk Pesaing Terhadap Perilaku Bran Switching Dengan Kebutuhan MencariVariasiSebagai Variabel Moderatingnya. Jurnal Ilmu Administrasi Bisnis, 1(1).

Sari, Deasy Purnama, Wahyu Hidayat, dan Widiartanto. 2014. Pengaruh Lifestyle, Efek Komunitas Dan Fitur Produk Terhadap Keputusan Brand Switching Smartphone Blackberry Ke Merek Lain. Jurnal Ilmu Administrasi Bisnis, 3(4), ha1.1-9.

Sugiyono. 2017. Statistika Untuk Penelitian. Bandung: Alfa Beta.

Suharseno, Teguh, Riskin Hidayat, dan Dian Ayu Liana Dewi. 2013. Pengaruh Ketidakpuasan Konsumen Dan Karakteristik Kategori Produk Terhadap Keputusan Perpindahan Merek Dengan Kebutuhan Mencari Variasi Sebagai Variabel Moderasi. Jurnal Buletin Studi Ekonomi, 18(2), hal. 176-182

Uturestantix, Ari Warokka, dan Cristina Gallato. 2012. Do Customer Dissatisfaction and Variety Seeking Really Affect the Product Brand Switching? A Lesson from the Biggest Southeast Asia Mobile Telecommunication Market. Journal of Marketing Research \& Case Studies, 2012(2012), hal.1-14.

Wibowo, Setyo F., Teguh K, dan Agung, KRP. 2014. Pengaruh Atribut Produk dan Variety Seeking Terhadap Keputusan Perpindahan Merek Handphone Nokia ke Smartphone Samsung. Jurnal Riset Manajemen Sains Indonesia 